Karolina Kulińska*

\title{
RECENTRALIZACJA SYSTEMU OPIEKI ZDROWOTNEJ W POLSCE. ZARYS PROBLEMU
}

\section{Uwagi wstępne}

Krytyka publiczna służby zdrowia związana z jej słabą efektywnością, niegospodarnością i wadliwymi rozwiązaniami instytucjonalnymi jest już w zasadzie stałym elementem zarówno debaty publicznej, jak i licznych opracowań naukowych. Z uwagi na częste zmiany normatywne w sektorze ochrony zdrowia i wiele niuansów składających się na specyfikę świadczenia usług leczniczych (jak chociażby konieczność ciągłego dostosowywania standardów do postępu technologicznego i naukowego w obszarze medycyny), trudno jest stworzyć uporządkowany i statyczny obraz istniejącego systemu. Stąd, spojrzenia na służbę zdrowia z perspektywy centralizacji i decentralizacji jako parametru opisu jej struktury instytucjonalnej staje się pomocne, ponieważ pozwala na uchwycenie głównych tendencji rozwojowych w tym obszarze. Przedmiotem analizy będzie przy tym decentralizacja, rozumiana jako „[...] ustawowy podział władzy politycznej, fiskalnej i administracyjnej pomiędzy rząd i samorządy terytorialne, który opiera się na podziale kompetencji i zadań między te władze. Ten podział stanowi podstawę decentralizacji finansów publicznych,

Karolina Kulińska - Zakład Porównawczej Administracji Publicznej, Instytut Nauk Administracyjnych, Wydział Prawa, Administracji i Ekonomii, Uniwersytet Wrocławski. 
czyli decentralizacji decyzji o wydatkowaniu środków publicznych, co sprzyja racjonalnemu ich wykorzystaniu"'. Jest to pojęcie relewantne, którego korelatem jest centralizacja, a więc „taki układ przedmiotowy, w którym istnieje jedno centrum jako źródło siły łączącej przedmioty w jedną całość”2.

\section{Początki współczesnej koncepcji publicznej ochrony zdrowia}

Nim podjęto rozważania w ramach centralizacji-decentralizacji systemów ochrony zdrowia i wpływu tych procesów na wydajność publicznej służby zdrowia, potrzebne było nie tyle uświadomienie sobie potrzeby ingerencji państwa w sferę zdrowia obywateli, ile również racjonalizacja przesłanek uzasadniających tę ingerencję. Przegląd różnych ujęć tej kwestii w sposób syntetyczny i przejrzysty przedstawił D. Szcześciło ${ }^{3}$, który wskazał pięć występujących dróg uzasadnienia dla publicznej ingerencji w sferze ochrony zdrowia. Po pierwsze, wyrosłe na gruncie Wielkiej Rewolucji Francuskiej uzasadnienie ideowe, zgodnie z którym zdrowie jest jednym z fundamentalnych praw przysługujących człowiekowi. Kolejnym przykładem jest występujące w Szwecji uzasadnienie utylitarne, gdzie ochrona zdrowia traktowana jest jako szczególne zadanie, które leży w interesie każdego państwa. Komunitaryści postrzegają ochronę zdrowia jako materię, o której każda wspólnota powinna decydować samodzielnie i bez narzucania w tej sferze jakiegokolwiek standardu. Inaczej niż dla egalitarystów, którzy postrzegali je jako dobro publiczne i co więcej - instrument wyrównywania szans. Wreszcie, radykalni libertarianie w ogóle odrzucają społeczną odpowiedzialność za zdrowie jednostek, w wersji umiarkowanej, dopuszczając jedynie elementy publicznego finansowania opartego na zasadzie voucherowej.

${ }^{1}$ A. Zalewski, Reformy sektora publicznego $w$ duchu nowego zarządzania publicznego [w:] Nowe zarządzanie publiczne w polskim samorzadzie terytorialnym, red. A. Zalewski, Warszawa 2005, s. 66.

${ }^{2}$ D. Szcześciło, Zmierzch decentralizacji? Instytucjonalny krajobraz opieki zdrowotnej w Europie po nowym zarządzaniu publicznym, Warszawa 2017, s. 18.

3 D. Szcześciło, Zmierzch..., s. 5-20. 
Aby można było mówić o systemie jako organizacji ludzi, instytucji i środków publicznych świadczących opiekę zdrowotną na rzecz obywateli, potrzebna była odpowiednia infrastruktura i powołanie wyspecjalizowanych instytucji, które to zaczęły się pojawiać w Europie pod koniec XIX w. Od tego momentu rozpoczęło się formowanie scentralizowanych systemów opieki zdrowotnej, które następowało poprzez „poszerzanie państwowego centralnego imperium w tej sferze kosztem samorządów lokalnych, instytucji prywatnych i kościelnych przy jednoczesnym ograniczaniu odpowiedzialności jednostek za swoje zdrowie" ${ }^{4}$. Innymi słowy, wiek XIX to okres centralizacji i konsolidacji, który umożliwił powstanie jednolitego aparatu administracyjnego ukierunkowanego na świadczenie usług leczniczych.

W okresie po drugiej wojnie światowej nastąpiła petryfikacja dwóch tendencji. Po pierwsze, ugruntował się status ochrony zdrowia jako szczególnego prawa jednostki i korespondującego z nim obowiązku państwa. Ochrona zdrowia przez państwo w takim ujęciu jest do dziś standardem konstytucyjnym i międzynarodowym. Natomiast w sferze stricte systemowej w państwach socjalistycznych przyjęto Model Siemaszki, czyli system centralnie planowany ${ }^{5}$. Trzonem tego modelu była centralizacja organizacji i finansowania sektora ochrony zdrowia oraz wynikająca stąd pełna kontrola państwa nad systemem. Inne wyróżniające cechy tego podejścia to zakłady opieki zdrowotnej będące własnością państwa i traktowanie pracowników służby zdrowia jak urzędników państwowych oraz finansowanie z budżetu państwa wszelkich działań związanych z ochroną zdrowia ${ }^{6}$.

Niewątpliwie państwowa służba zdrowia w Polsce do lat 90. ubiegłego stulecia pasowała do tej charakterystyki. Po przejściowym obowiązywaniu przepisów międzywojennych zaadaptowanych do realiów gospodarki planowej, w 1948 r. weszła w życie ustawa o za-

${ }^{4}$ D. Szcześciło, Zmierzch..., s. 5-20.

${ }^{5} \mathrm{~K}$. Wielicka, Zarys funkcjonowania systemów opieki zdrowotnej w wybranych krajach Unii Europejskiej, „Zeszyty Naukowe Politechniki Śląskiej. Seria: Organizacja i Zarządzanie" 2014/70, s. 494.

${ }^{6}$ K. Wielicka, Zarys..., s. 494. 
kładach społecznych służby zdrowia i planowej gospodarce w służbie zdrowia ${ }^{7}$. Filarem systemu opieki zdrowotnej od tego momentu była administracja państwowa. System ten miał zapewnić powszechny i bezpłatny dostęp do wszelkich form ambulatoryjnej opieki zdrowotnej. ${ }^{8}$ Odznaczał się centralizacją, a „szpitale i inne zakłady opieki zdrowotnej miały funkcjonować w jednym spójnym systemie opierającym się na gospodarce centralnej i planowej"’. Państwowe były także apteki, ograniczano możliwość świadczenia usług prywatnych, zaś personel medyczny był zatrudniany na etatach państwowych. Placówki służby zdrowia były zaś finansowane $\mathrm{z}$ budżetu państwa.

Od strony organizacyjnej na ówczesny model składały się państwowe placówki służby zdrowia oraz uzupełniająco uspołecznione placówki środowiskowe. Jednakże, jak zauważają Z. Nowak i G. Holik, „obydwa te filary, mimo pozornej atrakcyjności dostępu do usług medycznych, nie działały jednak sprawnie, głównie z przyczyn organizacyjnych i finansowych, co znajdowało odzwierciedlenie w pogarszającym się stanie zdrowia społeczeństwa. Okazało się, że socjalistyczne państwo nie było w stanie zaspokoić potrzeb medycznych ludności” ${ }^{\prime 1}$.

\section{Renesans decentralizacji}

Ostatnie dekady XX w. to okres rozproszenia władzy, kontroli i zasobów. Jak podkreśla D. Szcześciło, ważnym zjawiskiem jest pojawienie się Nowego Zarządzania Publicznego (New Public Management). Zdaniem autora na fali Nowego Zarządzania Publicznego systemy opieki zdrowotnej uległy rozproszeniu przez wzmocnienie roli władzy lokalnej i regionalnej oraz przejęcie świadczenia usług przez

7 Ustawa z 28.10.1948 r. o zakładach społecznych służby zdrowia i planowej gospodarce w służbie zdrowia (Dz.U. Nr 55, poz. 434 ze zm.).

${ }^{8}$ Do 1971 r. nie dotyczyło to rolników, nie dotyczyło to też niektórych leków.

9 Z. Nowak, G. Holik, Ewolucja systemu ochrony zdrowia w Polsce, „Zeszyty Naukowe Uniwersytetu Ekonomicznego w Krakowie" 2011/863, s. 17.

${ }^{10}$ Z. Nowak, G. Holik, Ewolucja..., s. 17. 
sektor prywatny. Znacząca część imperium i dominium przeszła nie tylko na samorządy lokalne i regionalne, ale również na sektor prywatny. Nastąpiło przejście od monopolu do rynku usług publicznych w celu zwiększenia zakresu świadczonych usług i zapewnienie ich lepszej jakości ${ }^{11}$.

Oczywiście dla funkcjonowania polskiego systemu opieki zdrowotnej najistotniejszą zmianą była transformacja ustrojowa, która z jednej strony stworzyła przestrzeń „sprzyjającą wolności mechanizmów rynkowych"12, z drugiej zaś spowodowała konieczność pilnego przeprowadzenia gruntownych reform. Zmiany następowały jednak w sposób powolny. Były one ukierunkowane przede wszystkim na wdrażanie rozwiązań zmierzających do stworzenia regulowanego rynku usług medycznych oraz racjonalizację kosztów w opiece zdrowotnej, w tym poprzez decentralizację sfery świadczenia usług, w wyniku czego usamodzielniła się większość zakładów opieki zdrowotnej. Rozpoczął się również proces prywatyzacji służby zdrowia. Działania te nie przyniosły jeszcze wówczas wzrostu efektywności sektora ochrony zdrowia.

Nadal cechował się on: „niską efektywnością, pogarszającą się jakością opieki medycznej, marnotrawstwem środków publicznych oraz narastającą niewydolnością systemu finansowania. Stale rosło zadłużenie placówek służby zdrowia, a okresowo powtarzane operacje oddłużania przynosiły tylko krótkotrwałe efekty"13.

Za moment osiągnięcia faktycznej decentralizacji przyjmuje się utworzenie w 1999 r. kas chorych. Jeśli jednak chodzi o ocenę ich funkcjonowania, to słusznie stwierdzają Z. Nowak i G. Holik, że krótki okres ich funkcjonowania (do roku 2003) nie pozwala na wyciągnięcie rzetelnych wniosków.

\footnotetext{
11 D. Szcześciło, Zmierzch..., s. 15-50.

${ }^{12}$ K. Wielicka, Zarys..., s. 495.

13 Z. Nowak, G. Holik, Ewolucja..., s. 18.
} 


\section{Zwrot w stronę centralizacji}

Tak zwana reforma centralizacyjna, polegająca na likwidacji kas chorych, miała wynikać z ich nadmiernej samodzielności i braku skutecznej formy nadzoru nad tymi autonomicznymi jednostkami. K. Wielicka podaje także jako jedną z przyczyn trudności związanych ze zmianami po 1999 r. roszczeniową postawę społeczeństwa mocno przyzwyczajonego do modelu opiekuńczego państwa oraz silnego upolitycznienia sektora zdrowia ${ }^{14}$. W ich miejsce utworzono Narodowy Fundusz Zdrowia, który przejął ich prawa i obowiązki, wynikające z umów o udzielaniu świadczeń zdrowotnych zawartych między kasami a świadczeniodawcami. W pierwotnej wersji, wprowadzonej ustawą z 23.01.2003 r. o powszechnych ubezpieczeniu w Narodowym Funduszu Zdrowia ${ }^{15}$, Narodowy Fundusz Zdrowia ${ }^{16}$ spotkał się z licznymi zarzutami ze strony Trybunału Konstytucyjnego, wśród których należy w tym miejscu wymienić naruszanie konstytucyjnego prawa obywateli do równego dostępu do świadczeń opieki zdrowotnej finansowanej ze środków publicznych.

Na skutek interwencji Trybunału Konstytucyjnego uchwalono kolejną ustawę z 27.08.2004 r. o świadczeniach opieki zdrowotnej finansowanych ze środków publicznych ${ }^{17}$, która obowiązuje obecnie. Zawarte w niej zmiany pozostały jednak bez wpływu na proces centralizacji wynikający z utworzenia NFZ. Zgodnie z założeniem reformatorów to rozwiązanie miało doprowadzić do zwiększenia transparentności prowadzonych działań dla świadczeniobiorców poprzez m.in. zawieranie umów według ujednoliconych procedur i standardów na określone świadczenia zdrowotne.

Nie wdając się w tym miejscu w szczegółowe rozważania co do zasadności tych założeń, należy jedynie zauważyć, że wprowadzone rozwiązania nie przyniosły spodziewanych rezultatów. Do dnia dzi-

${ }^{14}$ K. Wielicka, Zarys..., s. 496.

${ }^{15}$ Dz.U. poz. 391 ze zm.

16 Dalej jako: NFZ.

17 Dz.U. z 2018 r. poz. 1510 ze zm. - dalej jako: ustawa o świadczeniach opieki zdrowotnej finansowanych ze środków publicznych. 
siejszego miały miejsce inne, liczne zmiany, nie zawsze dające się powiązać jako węzłowe rozwiązania zmieniające paradygmat całego modelu. Jednym z ważniejszych kroków było wprowadzenie ustawy o działalności leczniczej ${ }^{18}$ w 2011 r., która uporządkowała i ujednoliciła terminologię prawną związaną z ochroną zdrowia, wprowadziła większą współodpowiedzialność organów założycielskich za finansowane placówki i uprościła procedurę komercjalizacji.

Zgodnie z art. 68 Konstytucji RP każdy ma prawo do ochrony zdrowia, a obywatelom, niezależnie od ich sytuacji materialnej, władze publiczne zapewniają równy dostęp do świadczeń opieki zdrowotnej ze środków publicznych. Jako najważniejsze organy i instytucje administracji publicznej wykonujące zadania z zakresu ochrony zdrowia należy wymienić: Ministra Zdrowia, Państwową Inspekcję Sanitarną, Prezesa Urzędu Rejestracji Produktów Leczniczych, Wyrobów Medycznych i Środków Biobójczych, Państwową Inspekcję Farmaceutyczną, Rzecznika Praw Pacjenta, konsultantów w ochronie zdrowia oraz jednostki samorządu terytorialnego.

Jeśli chodzi o rolę w polityce zdrowotnej państwa tych ostatnich, to pełnią one funkcję wykonawczą, kontrolując tworzone przez nie Samodzielne Zakłady Opieki Zdrowotnej. Samorządy terytorialne każdego szczebla posiadają również zadania własne związane z ochroną zdrowia, których przegląd zawiera tabela $1^{19}$.

Przedstawione regulacje nie ukazują jednak rzeczywistego udziału samorządu w systemie, przede wszystkim w uwagi na brak wystarczających zasobów do ich wykonywania. Przykładowo ustawa o świadczeniach opieki zdrowotnej finansowanych ze środków publicznych

18 Ustawa z 15.04.2011 r. o działalności leczniczej (Dz.U. 2018 r. poz. 160 ze zm.).

${ }^{19} \mathrm{~W}$ tabeli zawarto jedynie otwarty katalog (użyty przez ustawodawcę zwrot „W szczególności”) zadań wynikający z ustawy o świadczeniach opieki zdrowotnej finansowanych ze środków publicznych. Ustawy szczegółowe nakładają na jednostki samorządu terytorialnego także inne obowiązki, np. realizację zadań z zakresu profilaktyki i rozwiązywania problemów alkoholowych w postaci wojewódzkiego programu profilaktyki i rozwiązywania problemów alkoholowych - zgodnie z ustawą z 26.10.1982 r. o wychowaniu w trzeźwości i przeciwdziałaniu alkoholizmowi (Dz.U. z 2016 r. poz. 487 ze zm.). 
Tab. 1. Zadania własne jednostek samorządu terytorialnego w zakresie zapewnienia równego dostępu do świadczeń opieki zdrowotnej

\begin{tabular}{|c|c|c|}
\hline GMINA & POWIAT & WOJEWÓDZTWO \\
\hline $\begin{array}{l}\text { Opracowanie i realizacja } \\
\text { oraz ocena efektów progra- } \\
\text { mów polityki zdrowotnej } \\
\text { wynikających z rozpo- } \\
\text { znawanych potrzeb zdro- } \\
\text { wotnych i stanu zdrowia } \\
\text { mieszkańców gminy }\end{array}$ & $\begin{array}{l}\text { Opracowanie i realizacja } \\
\text { oraz ocena efektów } \\
\text { programów polityki } \\
\text { zdrowotnej wynikają- } \\
\text { cych z rozpoznawanych } \\
\text { potrzeb zdrowotnych } \\
\text { i stanu zdrowia miesz- } \\
\text { kańców powiatu - po } \\
\text { konsultacji z właściwymi } \\
\text { terytorialnie gminami }\end{array}$ & $\begin{array}{l}\text { Opracowanie i realizacja } \\
\text { oraz ocena efektów pro- } \\
\text { gramów polityki zdro- } \\
\text { wotnej wynikających } \\
\text { z rozpoznawanych po- } \\
\text { trzeb zdrowotnych } \\
\text { i stanu zdrowia miesz- } \\
\text { kańców województwa } \\
\text { - po konsultacji z właś- } \\
\text { ciwymi terytorialnie } \\
\text { gminami i powiatami }\end{array}$ \\
\hline $\begin{array}{l}\text { Przekazywanie powiatowi } \\
\text { informacji o realizowanych } \\
\text { programach polityki zdro- } \\
\text { wotnej }\end{array}$ & $\begin{array}{l}\text { Przekazanie marszałkowi } \\
\text { województwa informacji } \\
\text { o realizowanych na tere- } \\
\text { nie powiatu programach } \\
\text { polityki zdrowotnej }\end{array}$ & $\begin{array}{l}\text { Przekazanie wojewodzie } \\
\text { informacji o realizowa- } \\
\text { nych na terenie woje- } \\
\text { wództwa programach } \\
\text { polityki zdrowotnej }\end{array}$ \\
\hline $\begin{array}{l}\text { Inicjowanie i udział } \\
\text { w wytyczeniu kierunków } \\
\text { przedsięwzięć lokalnych } \\
\text { zmierzających do zazna- } \\
\text { jomienia mieszkańców } \\
\text { z czynnikami szkodli- } \\
\text { wymi dla zdrowia oraz ich } \\
\text { skutki, a także }\end{array}$ & $\begin{array}{l}\text { Prowadzenie działań } \\
\text { na rzecz indywidualnej } \\
\text { i zbiorowej odpowie- } \\
\text { dzialności za zdrowie } \\
\text { oraz na rzecz ochrony } \\
\text { zdrowia, a także }\end{array}$ & $\begin{array}{l}\text { Opracowanie i wdroże- } \\
\text { nie programów innych } \\
\text { niż określony w pkt } 1 \text {, } \\
\text { służących realizacji za- } \\
\text { dań w zakresie ochrony } \\
\text { zdrowia }\end{array}$ \\
\hline \multirow[t]{2}{*}{$\begin{array}{l}\text { Podejmowanie innych } \\
\text { działań wynikających z ro- } \\
\text { zeznanych potrzeb zdro- } \\
\text { wotnych i stanu zdrowia } \\
\text { mieszkańców gminy }\end{array}$} & $\begin{array}{l}\text { Podejmowanie innych } \\
\text { działań wynikających } \\
\text { z rozpoznanych potrzeb } \\
\text { zdrowotnych }\end{array}$ & $\begin{array}{l}\text { Inspirowanie i promowa- } \\
\text { nie rozwiązań w zakresie } \\
\text { wzrostu efektywności, } \\
\text { w tym restrukturyzacji } \\
\text { w ochronie zdrowia }\end{array}$ \\
\hline & & $\begin{array}{l}\text { Podejmowanie innych } \\
\text { działań wynikających } \\
\text { z rozpoznanych potrzeb } \\
\text { zdrowotnych }\end{array}$ \\
\hline
\end{tabular}

Źródło: opracowanie własne na podstawie ustawy z 27.08.2004 r. o świadczeniach opieki zdrowotnej finansowanych ze środków publicznych. 
nakłada na samorządy obowiązek przyjmowania programów polityki zdrowotnej, nie przewiduje jednak źródła ich finansowania. Co prawda w 2015 r. ${ }^{20}$ poza poszukiwaniem środków w dochodach własnych możliwe stało dofinansowanie realizacji samorządowych programów ze środków NFZ, nie było ono jednak obowiązkowe i zależało od możliwości finansowych danego oddziału funduszu.

Ponadto, jak wynika z przywołanych przez D. Szcześciło danych, jednostki samorządu terytorialnego w rzeczywistości nie mają kontroli nad finansami i dysponują jedynie marginalną częścią zsumowanych wydatków publicznych na ochronę zdrowia. W literaturze często podnosi się, że Polska ma najniższy spośród europejskich członków OECD poziom całkowitych wydatków publicznych na ochronę zdrowia mierzonych w relacji do PKB. Zauważano także tendencję spadkową wydatków na ochronę zdrowia w województwach (z 6\% całości wydatków w 2012 r. do 4,2\% w 2016 r.).

Jednocześnie rola samorządów jest kluczowa w sferze bezpośredniego świadczenia usług zdrowotnych. Większość szpitali publicznych w Polsce (82\%) jest ich własnością, kontrolują także większą część łóżek w szpitalach publicznych (78\%). Równie istotny jest ich udział w zarządzaniu innego typu placówkami zdrowotnymi (wspomniany SPOZ-y). Stwarza to bardzo dobre warunki do wykorzystania posiadanej przez samorządy kontroli jako instrumentu prowadzenia samorządowej polityki zdrowotnej, ale bez stworzenia odpowiednich warunków finansowych, pozostaje on niewykorzystany.

Za D. Szcześciło ${ }^{21}$ należy wymienić główne czynniki krępujące podmiotowość jednostek samorządu terytorialnego. Po pierwsze, jest to monopsoniczna pozycja Narodowego Funduszu Zdrowia jako dysponenta środków publicznych i podmiotu zamawiającego świadczenia. Narodowy Fundusz Zdrowia choć jest całkowicie niezależny od samorządu, determinuje sytuację finansową samorządowych świad-

${ }^{20}$ Art. 48 d ustawy z 27.08.2004 r. o świadczeniach opieki zdrowotnej finansowanych ze środków publicznych (Dz.U. Nr 210, poz. 2135 ze zm.).

${ }^{21}$ D. Szcześciło, Zmierzch... 
czeniodawców. Rezultatem takiego stanu rzeczy jest konflikt na linii świadczeniodawcy-płatnik. Co więcej, do 2015 r. NFZ łączył funkcję płatnika z odpowiedzialnością za wycenę świadczeń zdrowotnych, co stwarzało idealne warunki do wykorzystywania tej pozycji. Odpowiedzialność za wycenę świadczeń przejęła Agencja Oceny Technologii Medycznych i Taryfikacji, podlegająca jednak Ministerstwu Zdrowia.

W dalszej kolejności jest to kwestia chronicznego zadłużenia placówek. W latach 2003-2014 zadłużenie zmalało o dwie trzecie, jest to jednak główny problem służby zdrowia od lat 80 . Wreszcie, istotny jest problem niejasności co do dopuszczalności prowadzenia przez publiczne placówki ochrony zdrowia działalności komercyjnej. Stan prawny budzi wątpliwości, ale zgodnie z interpretacją Ministra Zdrowia z 2014 r. świadczeniodawca niebędący przedsiębiorcą (np. samodzielny zakład opieki zdrowotnej założony przez samorząd) nie może na zasadach komercyjnych udzielać świadczeń zdrowotnych mieszczących się w katalogu świadczeń gwarantowanych przez państwo, nawet jeśli wyczerpał już limit wynikający z umowy z Narodowym Funduszem Zdrowia lub takiej umowy w ogóle nie zawarł. Ograniczenie to nie dotyczy placówek pozostających pod kontrolą samorządów, ale przekształconych w spółki kapitałowe. Większość placówek to jednak nadal SPZOZ.

Wymienione czynniki zadecydowały o zakwalifikowaniu polskiego systemu opieki zdrowotnej do grona słabo zdecentralizowanych z punktu widzenia dewolucji wśród 30 przebadanych państw europejskich. Stwierdzono wręcz, że o ile na poziomie ustawowym obszar odpowiedzialności samorządów za tworzenie i realizację polityk zdrowotnych został zakreślony szeroko, ,to mechanizmy finansowania i zarządzania systemem opieki zdrowotnej uprawniają do radykalnego stwierdzenia, że mamy tu do czynienia z iluzją decentralizacji"22.

W społecznej świadomości winę za niewydolność systemu ponosi w głównej mierze Narodowy Fundusz Zdrowia. Ten zaś, zgodnie z założeniami reformy Narodowej Służby Zdrowia, ma od stycznia 2018 r.

${ }^{22}$ D. Szcześciło, Zmierzch..., s. 130. 
zastąpić państwowy fundusz celowy, którego dysponentem będzie Minister Zdrowia. Będzie się to wiązało z przeniesieniem kompetencji NFZ do Ministerstwa Zdrowia a Oddziały Wojewódzkie NFZ zostaną przekształcone w Wojewódzkie Urzędy Zdrowia, podległe ministrowi, a poziomo - wojewodom. Ratio legis tej zmiany jest według autorów projektu zamiana powszechnego ubezpieczenia zdrowotnego na zasadę powszechnego zabezpieczenia prawa do świadczeń dla wszystkich potrzebujących rezydentów Rzeczypospolitej. W ten sposób ma nastąpić realizacja standardów konstytucyjnych związanych z prawem do ochrony zdrowia. W założeniu zmiana ta ma urzeczywistnić równość w dostępie do publicznych świadczeń zdrowotnych przez niezostawianie „poza nawiasem” osób nieobjętych z różnych przyczyn składką na ubezpieczenie zdrowotne. Efektywność i gospodarność proponowanego rozwiązania mają wynikać ze zmniejszenia biurokracji związanej z panującym systemem weryfikacji uprawnień do korzystania ze świadczeń zdrowotnych (eWUŚ) oraz likwidacji kosztów związanych z mechanizmem poboru składek na ubezpieczenie zdrowotne i ich dofinansowania dla podmiotów nieopłacających składek i tych, za które składki i tak opłaca budżet państwa.

\section{Wnioski końcowe}

Nadchodzące przeobrażenia są dobrym momentem na refleksję w dwóch obszarach. Po pierwsze, czy zmiana finansowania służby zdrowia zasługuje na miano reformy recentralizacyjnej, czy też utwierdza status quo jedynie „iluzorycznie zdecentralizowanego” systemu? Ponadto, mając na względzie konstytucyjną zasadę decentralizacji władzy publicznej, skłania do analizy wad i korzyści procesów centralizacyjnych we wskazanym obszarze.

Jeśli chodzi o pierwsze z postawionych pytań, należałoby się skłonić ku stwierdzeniu, że mamy do czynienia z pewną formą recentralizacji. Niewydolność systemu przejawiająca się w tym, że na jednostki samorządu terytorialnego przerzucana jest duża część odpowiedzialności przy jednoczesnym niezapewnianiu im wystarczających środków i utrzymywaniu głównego ośrodka decyzyjnego w centrum, choć 
ten system wypacza, nie oznacza jednak, iż decentralizacja w ogóle nie ma miejsca (zwłaszcza w wymiarze normatywnym). Natomiast ocenę narastających tendencji można ocenić w dwóch płaszczyznach: empirycznej i teorii organizacji.

W ostatnich kilkunastu latach w państwach OECD przeprowadzano badania relacji między decentralizacją a efektywnością systemów ochrony zdrowia. Nie pozwalają one na wyprowadzenie jednoznacznych wniosków z powodu trudności spowodowanych m.in. mierników efektywności. Najczęściej stosowanym jest śmiertelność wśród noworodków i choć rzeczywiście jest to jeden z najwyraźniejszych wskaźników skuteczności służby zdrowia w danym państwie, to nie oddaje całej złożoności problemu. Zauważano jednak, że badania empiryczne potwierdzają teoretyczne założenia dotyczące najważniejszych uwarunkowań wpływających na rezultaty dewolucji. Jak pokazuje casus Włoch, dewolucja zawodzi nie tylko jako środek eliminacji terytorialnych nierówności w dostępie do opieki zdrowotnej, a wręcz może pogłębiać istniejące rozwarstwienie. Konieczne jest zatem uwzględnienie w reformach jakichś strategii łagodzenia terytorialnego zróżnicowania, realizując powszechny charakter prawa do ochrony zdrowia, np. poprzez subsydiowanie słabiej rozwiniętych terenów. Wskazane są także zachęty stymulujące władze lokalne i regionalne do gospodarnego i efektywnego zarządzania, w przeciwnym razie samorządy mogą ulec pokusie nieracjonalnego wydatkowania, skoro to rząd centralny ponosi największą odpowiedzialność, a nawet wywierać presję na administrację rządową, by udzielała im wsparcia w przypadku problemu ze zbilansowaniem samorządowego budżetu zdrowotnego.

Jako pozytywne aspekty decentralizacji, na gruncie teorii organizacji wymienia się silniejsze powiązania między decydentami i użytkownikami. Bliski kontakt z ludnością zwiększa szanse uświadomienia sobie jej potrzeb. Udział w decyzjach politycznych dotyczących ochrony zdrowia prowadzi do lepszego dopasowania preferencji oraz poziomów usług. To z kolei może prowadzić do efektu Tiebouta, czyli przenoszenia się świadczeniobiorców na tereny, gdzie obowiązują kombinacje podatków i/lub usług, które lepiej pasują do ich preferencji. Kolejny atut decentralizacji to ułatwienie koordynacji. Jak zauważają I. Kowalska i A. Mokrzycka, 
duże scentralizowane jednostki mają większą tendencję do opierania się na formalnych sposobach koordynacji poprzez standaryzację danych wejściowych i procedur, natomiast małe zdecentralizowane jednostki są bardziej elastyczne w kontekście koordynacji ad hoc. Potencjalne korzyści zdecentralizowanego procesu podejmowania decyzji to m.in. łatwiejsze wykorzystanie wiedzy i doświadczenia zgromadzonego przez lokalny zespół, poprawa elastyczności, zwiększona motywacja pracowników, stymulacja przedsiębiorczości, a nawet zwiększanie poczucia odpowiedzialności wśród pracowników ${ }^{23}$.

Polityka decentralizacji może być także skuteczna pod kątem ograniczania ryzyka tzw. zasobów wąskiego gardła na poziomie centralnym, dzięki czemu zwiększają ogólną wydolność systemu. Poprzez decentralizację decyzji dotyczących wdrażania władze scentralizowane zyskują więcej zasobów, które mogą skoncentrować na strategicznym planowaniu dla systemów opieki zdrowotnej ${ }^{24}$. Decentralizacja może zatem prowadzić to optymalizacji podziału siły roboczej w procesie decyzji politycznych. Pełna decentralizacja stwarza pole do eksperymentowania i zbierania doświadczeń, które następnie mogą być eksportowane do innych części systemu opieki zdrowotnej, co z kolei przekłada się na większy potencjał co do innowacyjności.

Zagrożenia, jakie niesie decentralizacja, to z kolei w teorii organizacji ryzyko niewystarczającej optymalności, wynikające z koncentracji jednostek na własnej wydajności zamiast na całości systemu. Decentralizacja prowadzi również do różnicowania praktyk i standardów, szczególnie w zakresie zarządzania personelem. Obniżona jest także porównywalność i przewidywalność na poziomie systemu.

Dodatkowo, na rzecz centralizacji danego stopnia władzy mogą przemawiać problemy koordynacji w systemach zdecentralizowanych oraz ryzyko powielenia usług, a także ograniczona zdolność zajmowania

${ }^{23}$ I. Kowalska, A. Mokrzycka, Analiza wybranych kryteriów wartościujących dla oceny procesów decentralizacji i centralizacji w ochronie zdrowia, "Zdrowie Publiczne i Zarządzanie" 2012/3, s. 171-178.

${ }^{24}$ I. Kowalska, A. Mokrzycka, Analiza..., s. 171-178. 
się złożonymi problemami, ryzyko wystąpienia zjawiska lobbingu oraz problemy skutków zewnętrznych i dzielenia zasobów, w sytuacjach, kiedy działania jednej jednostki administracyjnej negatywnie wpływają na działalność innej.

Ponadto centralizacja stwarza lepsze warunki do wdrażania centralnie zaprojektowanych decyzji strategicznych i dostarcza jasnych sygnałów dla sterowania organizacją. Centralizacja systemu może ułatwiać standaryzację procesów i usług, a więc poprawić przewidywalność w praktyce organizacyjnej służby zdrowia.

Jak wskazują I. Kowalska i A. Mokrzycka, gdy dodatkowo występują problemy w sferze równego traktowania, często wywołuje to presję publiczną lub polityczną na standaryzację i działania wyrównujące te zasady pomiędzy jednostkami. W celu realizacji powyższego może być niezbędny pewien stopień (re)centralizacji władzy politycznej i administracyjnej. Biorąc pod uwagę przedstawione powyżej przyczyny i założenia planowanej reformy, uprawnione jest stwierdzenie, że właśnie z taką tendencją mamy w tej chwili do czynienia.

\section{Bibliografia:}

Kowalska I., Mokrzycka A., Analiza wybranych kryteriów wartościujących dla oceny procesów decentralizacji i centralizacji w ochronie zdrowia, „Zdrowie Publiczne i Zarządzanie" 2012/3

Nowak Z., Holik G., Ewolucja systemu ochrony zdrowia w Polsce, „Zeszyty Naukowe Uniwersytetu Ekonomicznego w Krakowie" 2011/863

Szcześciło D., Zmierzch decentralizacji? Instytucjonalny krajobraz opieki zdrowotnej w Europie po nowym zarzadzaniu publicznym, Warszawa 2017

Wielicka K., Zarys funkcjonowania systemów opieki zdrowotnej w wybranych krajach Unii Europejskiej, „Zeszyty Naukowe Politechniki Śląskiej. Seria: Organizacja i Zarządzanie" 2014/70

Zalewski A., Reformy sektora publicznego w duchu nowego zarządzania publicznego [w:] Nowe zarzadzanie publiczne w polskim samorzadzie terytorialnym, red. A. Zalewski, Warszawa 2005 